\title{
INTEGRATED MUNICIPAL AND SOLID WASTE MANAGEMENT IN THE AMAZON: ADDRESSING BARRIERS AND CHALLENGES IN USING THE DELPHI METHOD
}

\author{
BENONE OTÁVIO SOUZA DE OLIVEIRA ${ }^{1}$, GERSON ARAUJO DE MEDEIROS ${ }^{2}$, MICHEL XOCAIRA \\ PAES $^{3} \&$ SANDRO DONNINI MANCINI ${ }^{2}$ \\ ${ }^{1}$ Federal University of Amazonas (UFAM), Campus Vale do Rio Madeira, Amazonas, Brazil \\ ${ }^{2}$ São Paulo State University (UNESP), Institute of Science and Technology, Sorocaba, Brazil \\ ${ }^{3}$ Fundação Getulio Vargas (FGV), São Paulo School of Management (FGV/EAESP), São Paulo, Brazil
}

\begin{abstract}
The Amazon is facing challenges for solid waste management, due to its social, environmental and economic vulnerabilities. The main goal of this research was to investigate barriers of integrated municipal solid waste (MSW) management for the Amazon, applying the Delphi method. A consultation with waste management experts allowed raising the main alternatives recommended for that geographical region. In addition, in loco surveys evaluated the MSW management of three cities from Southwest Brazilian Amazon (SWBRAM): Humaitá and Manicoré, in the state of Amazonas (AM), and Ariquemes, in the state of Rondônia (RO), Brazil. A total of 35 experts responded to the consultation, and there was unanimity that the prevention of solid waste generation should be encouraged in the Amazon. There was a consensus on the treatment of MSW in the Amazon: composting of organic waste (88\%) and recycling of dry waste (86\%), in addition to the disposal of MSW in landfills (83\%). The municipalities of Humaitá and Manicoré collect and dispose MSW in dumps. However, in Manicoré, there is a Recyclable Material Collectors Cooperative that diverts about $3.0 \mathrm{t} \mathrm{month}^{-1}$ of recyclable waste from the dump. Ariquemes disposes its MSW in the only sanitary landfill of SWBRAM, which receives about $135 \mathrm{t}_{\text {day }^{-1}}$ of the MSW generated in the 14 municipalities that form an Inter-municipal Consortium. The main challenges raised for the MSW management in the Amazon were as follows: investments in preventing MSW generation; supporting the creation of Cooperatives and the social inclusion of waste collectors; improving and integrating the river and road modals; creating conditions for the commerce of materials in Manaus recycling market; and supporting the creation of Inter-municipal Consortium for landfill construction and operation.
\end{abstract}

Keywords: sanitary landfill, recycling, composting, waste pickers.

\section{INTRODUCTION}

The economic development associated with fast industrialization, urbanization and population growth has intensified the generation/rate of municipal solid waste (MSW), including those from households, urban cleaning and commercial sector [1]. Consequently, public managers are challenged to find alternatives for the integrated MSW management and to reduce the risks of damage to the environment and human health, especially in developing countries [1], [2].

In Brazil, the National Policies on Solid Wastes (NPSW) (Law No. 12305 of 2010) provides a hierarchy of guidelines for the management of MSW [3]. This hierarchy prioritizes the prevention and minimization of MSW generation, as well as concerning the reutilization, recycling, recovery (including energetic) and elimination/disposal (incineration or landfill disposal) [2]. However, the contrasting reality of a continental-size country like Brazil makes it difficult to adopt MSW management systems indistinctly, throughout its territory, such as those proposed in the NPSW and disseminated in developed countries. 
In this context, the Brazilian Amazon is characterized by environmental, social and economic vulnerabilities, reflected in the significant disposal of MSW in dumps, in more than $80 \%$ of its municipalities. In addition, demographic and territorial aspects such as low population density and structural aspects (logistics and incipient industrial park) limit the alternatives for the integrated MSW management in this region [2].

The Amazon is a hotspot region on the planet due to the threat to its biodiversity, the forest burning to expand the agricultural frontier and mining in indigenous areas. Nevertheless, little attention has been given to issues that interfere with the quality of life of its urban population, notably those that live outside its metropolitan regions, as the worst levels of basic sanitation in Brazil are in this region [4].

This panorama is reflected in the considerable scarcity of scientific research related to the MSW management in the Amazon, even considering its entire scope in South America [5]. In the period from 2007 to 2019, a bibliographic research carried out in international databases on MSW management in the South American Amazon recovered only 16 articles published in scientific journals, revealing the shortage of knowledge production and its different impacts on the communities living in that region [5]. The results of this previous research led to the present article, which aims to conduct a deeper discussion on barriers and challenges of alternatives for integrated MSW management in the Amazon, through consultation with experts and applying the Delphi method.

\section{CHARACTERISTICS OF THE AMAZON}

The Amazon is distributed in nine countries (Bolivia, Brazil, Colombia, Ecuador, Guyana, French Guiana, Peru, Suriname and Venezuela), covering an area of approximately 7.5 million $\mathrm{km}^{2}$, which corresponds to $7 \%$ of the total surface of the Earth and $40 \%$ of the South American area [6].

Brazil has the largest absolute area in the Amazon (5.0 million $\mathrm{km}^{2}$ or $67 \%$ of the total area), with contributions from nine states: Acre (AC), Amapá (AP), Amazonas (AM), Pará (PA), Rondônia (RO), Roraima (RR), Tocantins (TO), Mato Grosso (MT) and Maranhão (MA) (Fig. 1) [5].

Despite its vast area, the Amazonian population was estimated at 28 million inhabitants, or only $8 \%$ of the sum of the populations of these nine countries, with Brazil presenting the highest number of people living in this region (24 million people) [7].

The climate of the region is humid equatorial, with annual average temperature varying from $26^{\circ} \mathrm{C}$ to $28^{\circ} \mathrm{C}$ and rainfall exceeding 2,000 mm per year [6]. Figure 1 shows the Amazon region, highlighting the three municipalities from Southwestern Brazilian Amazon and the localization of the dump areas (Manicoré and Humaitá) and the sanitary landfill (Ariquemes).

In this region, the municipality of Humaitá (AM) stands out for its fluvial logistical potential, on the banks of the Madeira River, one of the main affluents of the Amazon River. This municipality is located at $07^{\circ} 30^{\prime} 22^{\prime \prime} \mathrm{S}$ and $63^{\circ} 01^{\prime} 15^{\prime \prime} \mathrm{W}$ and $90 \mathrm{~m}$ a.s.1., $700 \mathrm{~km}$ distant from the metropolitan region of Manaus, Amazonas State capital. In the dry season, there is the possibility of accessing Manaus by land, via BR-319 highway. However, in the rainy season, only river transport is possible. Humaitá had an estimated population of 56,144 inhabitants in 2020 , spread over $33,111 \mathrm{~km}^{2}$ or 1.70 inhabitants $\mathrm{km}^{-2}$. Its per capita gross domestic product (GDP) reaches US\$2,200.00 [8].

The municipality of Manicoré (AM) $\left(05^{\circ} 48^{\prime} 33^{\prime \prime} \mathrm{S} ; 61^{\circ} 18^{\prime} 01^{\prime \prime} \mathrm{W} ; 45 \mathrm{~m}\right.$ a.s.l.) is about $390 \mathrm{~km}$ distant from Manaus, with access only by the Madeira River, on a trip with duration of 30 hours, by boat, or 60 to 90 hours, by ferry, depending on the navigability conditions of the Madeira River. The municipality shares a land border with Humaitá and has the only 


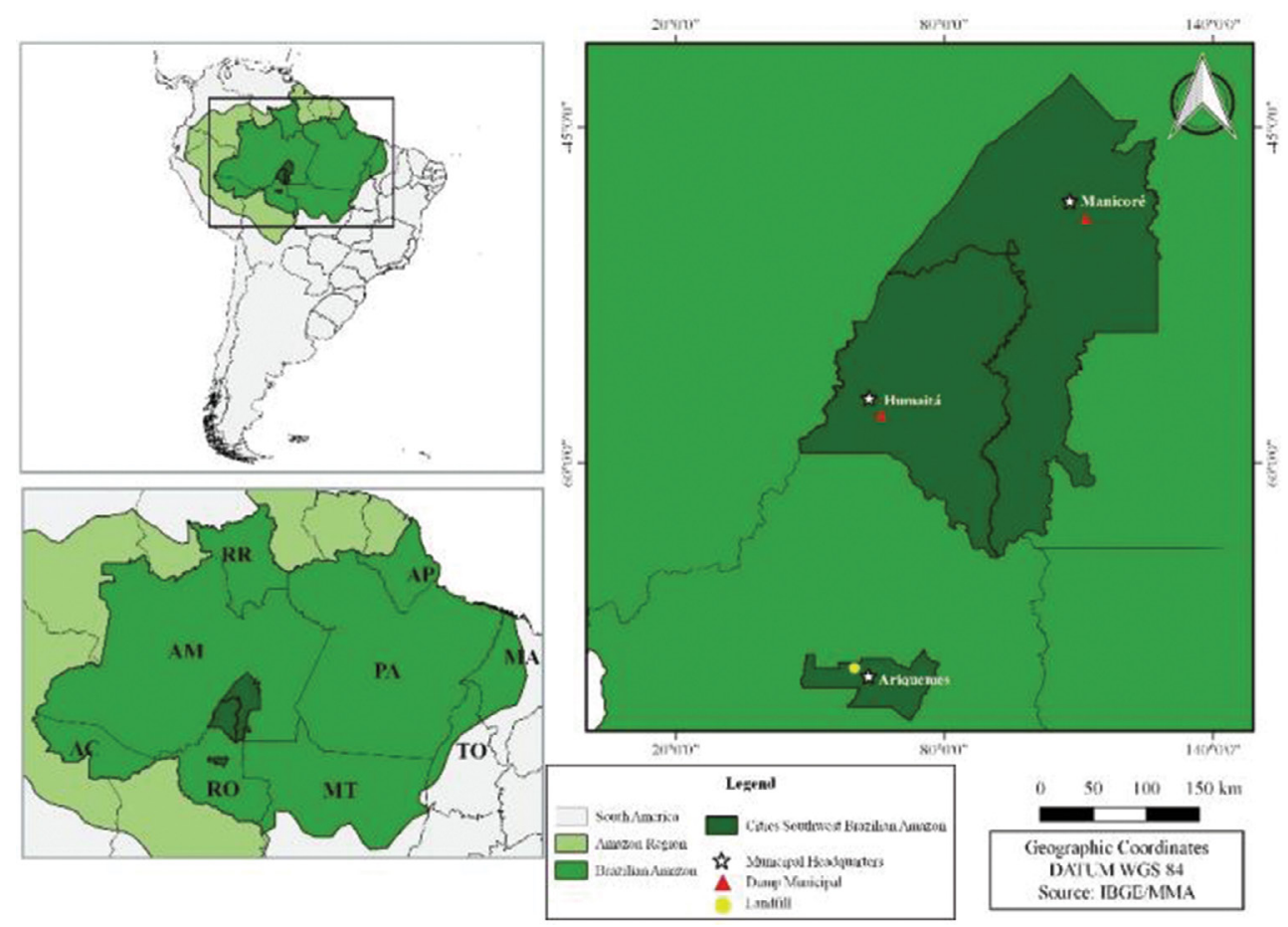

Figure 1: Amazon region extension, highlighting the Southwest Brazilian Amazon.

Recyclable Material Collectors Cooperative from SWBRAM. Its population was estimated at 56,580 inhabitants in 2020, spread over an area of $48,315 \mathrm{~km}^{2}$ or 1.17 inhabitants $\mathrm{km}^{-2}$ and a per capita GDP reaching US\$2,330.00 [9].

Ariquemes ( $09^{\circ} 54^{\prime} 17^{\prime \prime} \mathrm{S} ; 63^{\circ} 02^{\prime} 58^{\prime \prime} \mathrm{W} ; 142 \mathrm{~m}$ a.s.l.) is located $200 \mathrm{~km}$ distant from Porto Velho, Rondônia State capital, and 400 km from Humaitá, being connected to both by BR 364 highway. The population of this municipality was the largest among those evaluated, estimated at 109,500 inhabitants, in 2020. Its area was also the smallest $\left(4,427 \mathrm{~km}^{2}\right)$ leading to the highest observed population density ( 24.73 inhabitants $\mathrm{km}^{-2}$ ), in addition to the highest per capita GDP (US\$ 4,900.00) [10]. Ariquemes disposes its generated solid waste in the only SWBRAM's sanitary landfill.

Humaitá, Manicoré and Ariquemes have an incipient industrial sector, restricted to the agroindustry for processing nuts and dairy products. In the three municipalities, plant extraction, mining and livestock activities stand out [11], [12].

\section{MATERIAL AND METHODS}

\subsection{Consultation with experts: MSW management strategies in the Amazon}

The Delphi method, a consensus-building tool, was used for this research by surveying expert opinions. This method has the main advantages of overcoming problems related to face-toface meetings, such as the influence of outspoken person or collective group thinking dominating the outcome, and the dispersion of the goals of the discussion [13], [14]. In addition, it is an effective approach when experts are geographically dispersed and allows them to 
communicate their opinions anonymously [14]. The disadvantages related to this method include the potential for a careless execution, questionnaires elaborated in a dubious or confusing way, fatigue caused when answering a high number of questions, inadequate selection of panel members, unreliable results analysis, limited feedback and consensus, among others [13]. However, these problems are not exclusive to this research approach, and the Delphi method allows all participants an equal opportunity to be involved in the decision-making process [13]. Delphi method has been applied in waste management for the selection of technologies for treatment and disposal of MSW [15] and waste electrical and electronic equipment [14] and to identify barriers to implementation of the MSW management alternatives in developing countries such as Mozambique [16], Iran [17] and Vietnam [18]. A semi-structured questionnaire with closed questions was developed in the Google docs platform and, later, applied to specialists to evaluate the strategies of MSW management in the Amazon.

The selection of specialists was carried out through a survey on the Lattes curriculum platform, a database developed by the National Council for Scientific and Technological Development (CNPq), in Brazil. In this research, the inclusion criterion was the performance of the experts in MSW management area, in addition to their link with a higher education or research institution. Initially, 100 experts were selected, to whom an email message was sent with information about the study objective, the SWBRAM characteristics, a free and informed consent term and the link to access the questionnaire on the Google docs platform. After three rounds, the survey was completed with responses from 35 experts, which was superior to other studies related to MSW management, such as [14], [16], [17], [18].

There are several levels of agreement in the literature to evaluate the opinion convergence among experts [19]. In this study, the consensus degree considered was 50\% experts for each question assessed.

In the stages of applying the Delphi method, experts evaluated the questions using a Likert scale, assigning a degree of importance to each indicator, with values ranging from 1 (not completely agree) to 5 (totally agree) [13], [17].

The data were analysed and validated by the software Statistical Package for the Social Sciences (IBM SPSS, version 22.0). The reliability test was based on Cronbach's $\alpha$ coefficient, which varies between 0 and 1 ( $\alpha$ values greater than 0.7 allow to affirm the reliability of the scale) [20].

\subsection{Overview of MSW management in the Southwestern Brazilian Amazon}

In Humaitá, Manicoré and Ariquemes cities, MSW management was investigated in loco. The surveys included a visit to the Humaitá dump area, an interview with members of the Manicoré Recyclable Material Collectors Cooperative, secondary data collection in Intermunicipal Consortium reports and an interview with the Ariquemes landfill manager. In Manicoré, the investigation made it possible to assess the potential and limitations of the collection and commercialization of recyclable material by the only formal cooperative of waste pickers in the Southwest Brazilian Amazon [4]. In Ariquemes, the potential and limitations in the Amazon environment of the only SWBRAM sanitary landfill were raised.

\section{RESULTS AND DISCUSSIONS}

4.1 MSW management strategies in the Amazon: experts' perspective

Based on the $35 \%$ return of a panel with 100 specialists and Cronbach's $\alpha$ coefficient (greater than 0.7 ), the reliability of the Delphi method was demonstrated [20]. Approximately 54\% 
of the specialists were male and $46 \%$ female, predominantly those from the Southeast and South regions $(60 \%)$ in Brazil. These regions have quite different economic, social and environmental profiles from the Amazon, as they are the most industrialized, and geographically concentrate the Brazilian GDP as well as its population and have a greater variety of technological alternatives in the integrated management of MSW [21], [22]. In the north region, where about $90 \%$ of the Brazilian Amazon is located, $11 \%$ of the specialists participating in the research lived, which indicates a lower availability of professionals in the MSW management in the Amazon. The shortage of the skilled workers in solid waste management was a barrier highlighted by experts of studies applying Delphi method in developing countries [16], [17], [18].

Therefore, the panel of selected experts allowed an analysis with different views and academic trajectories, familiar with the guidelines of NPSW [3], and providing a comprehensive contribution to the MSW management in the Amazon region.

The experts were unanimous $(100 \%)$ in recommending prevention as an alternative for the management of MSW in the Amazon. Thus, investments in environmental education actions or programmes, as so as population engagement would be necessary to prioritize the prevention and reduction, are in line with the NPSW guidelines [3]. This result is corroborated for MSW management studies based on application of the Delphi technique, where they have been recommended investing in environmental culture and education to increase the population's willingness to cooperate and participate in MSW practices [17], change behaviour [16] and reduce sociocultural disadvantages [18].

The composting of organic solid waste (88\%) and the recycling of dry solid waste (86\%) were the MSW treatment alternatives recommended by the experts, followed by the disposal in the landfill (83\%), as recommended by other Brazilian authors [23], [24]. Composting of organic matter was considered the most suitable technology for the treatment of solid waste in Mumbai, India, according to the opinion of a panel of experts, applying the Delphi method [15]. However, this technology has a limited application in the Amazon region for the treatment of organic residues, due to the low rate of waste sorting, lack of investments, cost of maintenance and operation of the composting units in regions of high rainfall and the use of the compost generated [25].

Waste sorting at source and recycling have been recommended by experts in other developing countries such as Mozambique [16] and Iran [17]. However, a barrier is the absence of economic incentives to promote the waste hierarchy concepts [16], [18].

MSW recycling rate in Brazil reaches only 3.4\%, being even lower in the Amazon region [4]. The causes for this low rate of MSW recycling include the lack of integration of the informal recycling sector in the formal system, population awareness, municipal government support, an incipient recycling chain and the uniform distribution of companies in this sector in the national territory. Recycling companies are concentrated in the south and southeast regions of Brazil, where approximately $56 \%$ of the Brazilian population lives [4], [26]. There was a consensus of $94 \%$ of specialists that the recycling chain in the Amazon should be associated with the creation of Recyclable Waste Collectors Cooperatives, due to the possibility of social inclusion and improving the MSW management in low-income locations. However, in cities with lower tax revenues, these cooperatives lack adequate technologies, physical and regulatory structure, financing and support from the public authorities [25]. The inadequate fee for collection and treatment services was also one of the barriers pointed out by experts in Vietnam to justify the ineffective financial investment in MSW management system [18].

The results showed unanimity among experts that the lack of strategies by the municipal government is a barrier to attract recycling companies to SWBRAM. Next, low population 
and logistics density (83\%), low MSW generation (74\%) and production and consumption patterns $(63 \%)$ were highlighted.

Only $13 \%$ of the municipalities in the Brazilian Amazon have their MSW disposed in sanitary landfills [4]. Therefore, the creation of Inter-municipal Consortium reached a consensus of $77 \%$ of the specialists, as a way to make possible the installation and operation of more sanitary landfills in the Amazon and, thus, to optimize the final disposition and economic sustainability of the associated municipalities, due to the possibility of apportioning the costs involved in the administration and operation, optimizing financial resources and investment in technologies of environmental control and leachate treatment [27]. In addition, the landfill is the least costly alternative to any other technology option for MSW treatment, such as recycling, incineration and bio-methanization [21], [24].

Incineration technology has been widely adopted in developed countries; however, a significant portion of specialists (80\%) have not recommended this alternative for the management of MSW in the Southwestern Brazilian Amazon because of the relatively higher cost compared to other treatment technologies [21], [24]. Moreover, it requires a daily production of waste (240 t day $\left.{ }^{-1}\right)$ achieved only in the metropolitan regions of Manaus (AM) and Belém (PA) [4]. In developing countries, as India, the high organic content of MSW (60\% to 70\%) makes incineration technology unfeasible and favours bio-methanization and gasification treatments, according to expert consensus [15].

There was a consensus of the experts about the main causes for the problems of MSW management in the countryside of the Amazon region: lack of trained professionals to design, operate and monitor a landfill (91\%), followed by the lack of financial incentives to meet the agenda of the Brazilian National Policy on Solid Waste (89\%), difficulties in implementing the structure of waste collectors' cooperatives or associations (77\%) and the lack of knowledge about the legislation (57\%), corroborating other studies related to consulting specialists on MSW management applying the Delphi technique [16], [17], [18].

The management of MSW can add economic gains, in addition to improving the organization of the territorial space of municipalities in the Amazon, according to the consensus of $86 \%$ of the panel of experts. These economic gains can be enhanced through the circular economy, as indicated for other regions of Brazil [22]. Therefore, the MSW management problems can be overcome by the valorization of waste and its transformation into a financial asset [22], [28].

Finally, these results have pointed out that technical difficulties are an important aspect for the low performance of the integrated MSW management system in the SWBRAM [25], [26].

\subsection{MSW management in the Southwestern Brazilian Amazon}

Based on the experts' recommendations, an in loco survey script was developed to assess the potential of the alternatives for managing MSW in SWBRAM.

\subsubsection{Overview of MSW management in Humaitá (AM)}

The MSW management in the Amazon, in more than $80 \%$ of its municipalities, comprises the collection, transport and disposal of the waste in dumps [2]. The city of Humaitá followed this trend, as the collection of MSW has been carried out without any waste sorting, and, subsequently, it has been transported and disposed in a municipal dump since 1995. Sewage sludge from households has also been deposited in the dump because the municipality does not have a system for collecting and treating sewage. 
Humaitá city generates about 4,070 t year ${ }^{-1}$ of MSW $\left(0.41 \mathrm{~kg}^{\text {day }}{ }^{-1}\right.$ per inhabitant $)$, consisting of $47 \%$ organic waste, $40 \%$ recyclable waste (paper, plastic, metals, long-life packaging and glass) and $13 \%$ other non-recyclable materials [24].

The municipal dump was located $10 \mathrm{~km}$ from the urban spot, at the edge of the BR 319 highway that connects Humaitá to Porto Velho (RO) (Fig. 1). Within a radius of $2 \mathrm{~km}$ from the dump, it is possible to observe a higher education institution (Instituto Federal do Amazonas), a housing complex of 500 houses and an airport, which was closed due to the risk of accidents involving birds from the dump. During the rainy season, the place was flooded and access conditions made the provision of MSW unviable. In addition, the drained water reached streams $130 \mathrm{~m}$ away from the dump [5].

In the dump area, there were waste pickers who worked without any type of personal protection. The collected recyclable materials were sold to a scrap dealer and, subsequently, transported and sold in the city of Porto Velho (RO), for later shipment to the metropolitan region of the city of São Paulo, 3,000 km away from Porto Velho.

\subsubsection{Overview of MSW management in the municipality of Manicoré (AM)}

The municipality of Manicoré followed the same trend as Humaitá, as it has collected, transported and disposed its MSW in a dump, since 2003, without any kind of sorting. MSW generation reached around 4,380 $\mathrm{t}_{\text {year }}{ }^{-1}\left(0.42 \mathrm{~kg}\right.$ day $^{-1}$ per inhabitant $)$, with a predominance of organic waste $(52 \%)$, followed by recyclable waste $(43 \%)$ (paper, plastic, metals and glass) and other materials (5\%) [29]. However, Manicoré has been the only municipality in SWBRAM with a cooperative of 25 waste collectors and supported by the Manicoré Environment Department since 2010 [4].

Waste collectors had a residence, the association's headquarters, to store and separate the material collected from the streets of Manicoré. In this location, the manual screening process of the MSW, without any type of personal protective equipment, separated $2.5 \mathrm{t} \mathrm{month}^{-1}$ to $3.0 \mathrm{t} \mathrm{month}^{-1}$ of plastic, paper and aluminium, which were stored in bags, without compaction, since there was no mechanical press in the Cooperative.

The separated waste was sent by boat to the city of Manaus, to be sold. The transportation cost reached US\$ 30.00 per ton of MSW. Despite the distance, Manaus is the only city in the state of Amazonas with an industrial recycling segment. However, there were no industries for the recycling of glass, long-life packaging or ferrous metals, and, consequently, these materials had a low value, making their collection, transport and commercialization unfeasible.

\subsubsection{Overview of MSW management in Ariquemes (RO)}

The MSW management in Ariquemes differs from that of Humaitá and Manicoré, as the municipality has collected, transported and disposed the MSW, with no sorting, in a sanitary landfill $7 \mathrm{~km}$ away from its urban area, since 2012 (Fig. 1). The sanitary landfill has a maximum capacity of $150 \mathrm{t} \mathrm{day}^{-1}$, and it is managed by the Inter-municipal Sanitation Consortium of the Central Region of Rondônia, comprising 14 municipalities located within a radius of up to $95 \mathrm{~km}$, corresponding to 354,000 inhabitants of the State of Rondônia [30]. Before the landfill operation, all 14 municipalities disposed the solid waste in dumps [12].

Ariquemes city generates about 20,214 $\mathrm{t} \mathrm{year}^{-1}$ of $\mathrm{MSW}\left(0.63 \mathrm{~kg}_{\text {day }}{ }^{-1}\right.$ per inhabitant $)$, superior to Manicoré and Ariquemes because of the higher per capita GDP. However, the waste gravimetry follows the same trend of these municipalities, corresponding to $51 \%$ organic waste, $41 \%$ recyclable waste (paper, plastic, metals, long-life packaging and glass) and $8 \%$ other materials [12]. The high organic matter content (upper to 40\%) and the generation per 
capita in Humaitá, Manicoré and Ariquemes cities were close to other Amazon regions of South America, from Bolivia, Peru and Venezuela [5].

The Ariquemes landfill has a biological sludgy treatment system, an anaerobic lagoon, a facultative lagoon and a maturation lagoon [30]. The dimensioning of this system took into account the average rainfall of the region $\left(2,100 \mathrm{~mm} \mathrm{year}^{-1}\right)$. However, in 2016, the lagoons overflowed due to intense rainfall, demonstrating the vulnerability of sanitation facilities in the Amazonian environment. Another rain interference occurs in the process of compacting and grounding solid waste in the landfill cells.

The landfill operational cost reaches around US\$ 44,000 per month, including maintenance, labour, fuel and energy consumption. The municipalities of the consortium spend about US\$ 0.07 (t.km) $)^{-1}$, or US\$27,600 per month, in the MSW transport, with the total costs being proportionally split among them [30]. The sanitary landfill was built with a structure for the separation of dry recyclable waste, to extend its useful life, estimated at 14 years. However, the lack of a market to sell recyclable materials made the use of this structure unfeasible, which could provide economic and social benefits.

Therefore, difficulties involved in transporting and compacting the wastes, as well as problems in operating effluent treatment systems, especially during the rainy season, are among the main problems of the sanitary landfills located in the Amazon region.

\subsection{MSW management in the Amazon: barriers, gaps and challenges}

Based on the results of the consultation with specialists and on the in loco assessment of the SWBRAM municipalities, it was possible to outline the main barriers, gaps and emerging challenges for the MSW management in the Southwest of the Brazilian Amazon (Table 1).

The MSW management in the Amazon involves encouraging investments in environmental education programmes to reduce the generation of MSW and its irregular disposal in the landscape. Composting of organic residues and recycling of dry solid waste, alternative treatments for MSW recommended by specialists, depend on the sorting of MSW, present only in Manicoré under precarious conditions. The Amazon climate demand covered structures for composting and a programme to use the organic compost.

Low waste generation, logistical problems, the absence of recycling industries and a market to sell these materials are barriers to recycling at SWBRAM. In this context, priority should be given to sorting, recovery and packing recyclable materials and their fluvial transport along the Madeira waterway, to be sold in the city of Manaus, the only recycling market available in the state of Amazonas. The Madeira waterway is the second most important in the Amazon, as it transports about 5.3 million tonnes per year of Brazilian freight, highlighting soybean grains (2.6 million tonnes per year) [31]. These grains arrive at the river port of Porto Velho (RO), beginning of the waterway, and travel 1,060 km to its mouth, in Itacoatiara city (AM), about $100 \mathrm{~km}$ from Manaus (AM) [31]. The relative importance of this agricultural commodity in the total transported freight (about 50\%) imposes seasonality on the logistic system. During the harvest period (February to May), about $60 \%$ of the total soybean production is transported on the Madeira waterway, while in the inter-harvest (August to November), this value is reduced to $10 \%$ [32]. In this way, the transport of recyclable materials could optimize the transport structure of the Madeira waterway, as the waste is generated throughout the year.

Ariquemes is about $200 \mathrm{~km}$ far from Porto Velho city (RO), by road, allowing to access the Madeira waterway. Humaitá and Manicoré are located on the banks of the Madeira River and 


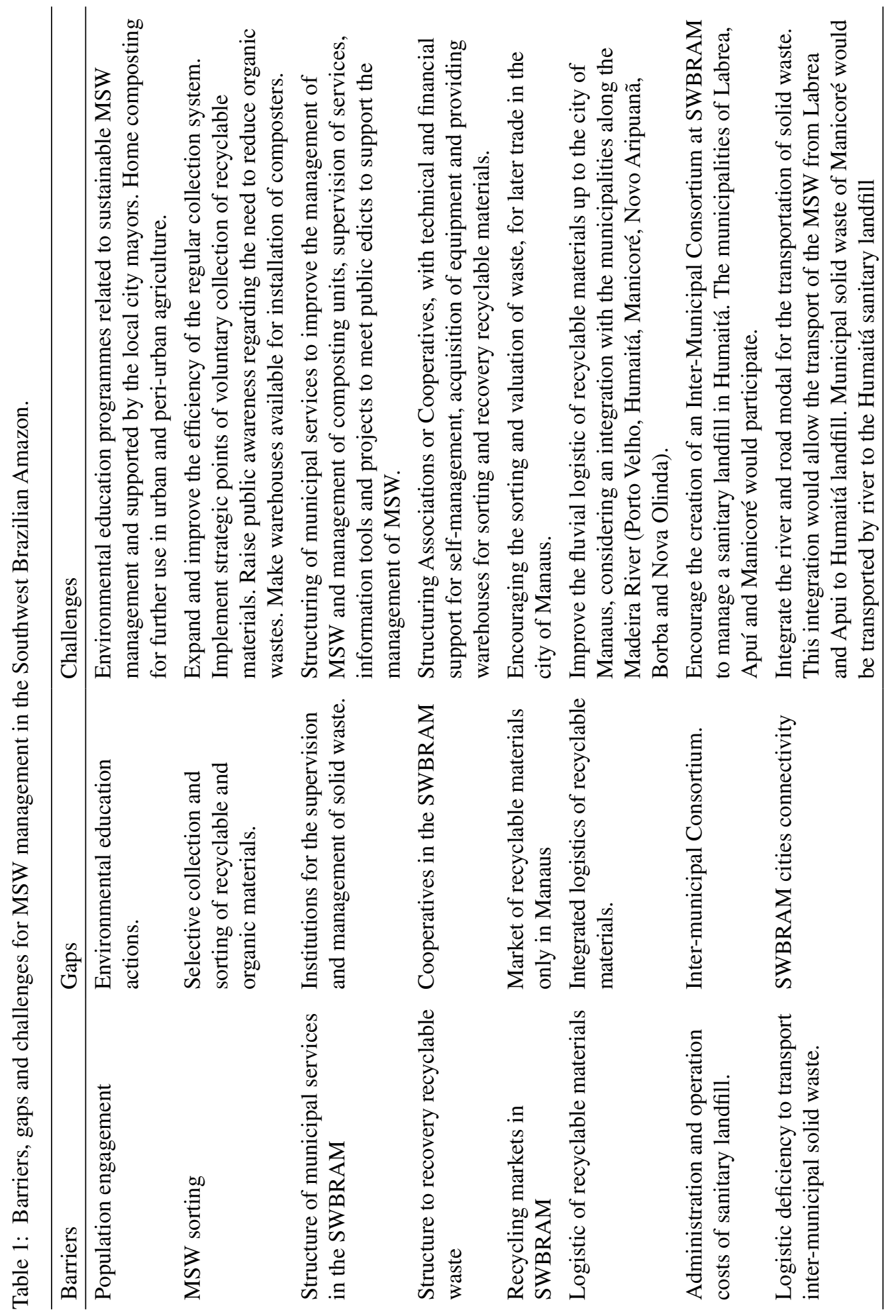


export products to Manaus. Humaitá could also receive recyclable materials, by road, from the Lábrea and Apuí municipalities and later sending to Manaus by Madeira waterway. This river logistics can be integrated with the municipalities located on the Madeira waterway (Porto Velho, Humaitá, Manicoré, Novo Aripuanã, Borba and Nova Olinda).

An Inter-municipal Consortium could be created to manage a sanitary landfill in Humaitá, according the consensus of experts. Potentially, the municipalities Humaitá and Manicoré, including Lábrea and Apuí, which dispose waste in dumps, could participate, representing a population of approximately 182,000 people [33]. Humaitá would receive MSW generated in Lábrea and Apuí, by road, and that generated in Manicoré, by the Madeira waterway.

\section{CONCLUSIONS}

The panel of experts recommended the prevention, composting, recycling and disposal in sanitary landfills for the integrated management of MSW in the Southwest Brazilian Amazon (SWBRAM).

Except for prevention, related to programmes to promote culture and environmental education, the other alternatives are intrinsically linked to the sorting and logistics of materials.

Composting and recycling depend, at first, on the sorting of solid waste. Therefore, the creation of Recyclable Waste Pickers' Cooperatives is a guideline of Brazilian NPSW to social inclusion and improving the MSW management in low-income locations. Composting in the Amazon will require structures for covering solid waste, due to the high rainfall in that Brazilian region. However, livestock production in the region may use the compost as a source of nutrients for pastures.

An incipient industrial park in SWBRAM makes this region a potential exporter of recyclable materials and, for that purpose, an integration of river and road modes is essential. The lower availability of highways in the Amazon is offset by river transportation, especially in SWBRAM, in which the Madeira waterway stands out. Through this waterway, recyclable materials can be transported from the municipalities of Ariquemes, Humaitá and Manicoré to the city of Manaus, in addition to other cities in this region, such as Porto Velho, Apuí and Lábrea. In addition, financial incentives could be granted to reduce the cost of river logistic of recyclable materials and to optimize the structure of the Madeira waterway, which has periods of lesser use due to the seasonality of agricultural commodity transport.

Another important consensus of experts, supported by the successful case of Ariquemes, concerns the creation of an Inter-municipal Consortium to build, operate and manage a sanitary landfill in Humaitá. This Consortium would include Lábrea, Apuí and Manicoré cities, which dispose waste in dumps. Once again, this alternative will depend on the integration of river and road modes for material logistics.

The panel of specialists applying Delphi method permitted to evaluate and select the most suitable alternative for the management of solid waste in the Amazon. This method, associated with in loco surveys of social, economic, demographic and structural aspects, allowed raising the barriers, gaps and challenges to be addressed for an integrated management of solid waste in the Amazon.

\section{REFERENCES}

[1] Paes, M.X., Mancini, S.D., de Medeiros, G.A., Bortoleto, A.P. \& Kulay, L.A., Life cycle assessment as a diagnostic and planning tool for waste management: a case study in a Brazilian municipality. Journal of Solid Waste Technology and Management, 44, pp. 259-269, 2018. https://doi.org/10.5276/jswtm.2018.259 
[2] Oliveira, B.O.S. \& Medeiros, G.A., Evolution and challenges in the urban solid waste management in the states of North region, Brazil. Revista Valore, 4(1), pp. 749-761, 2019 (in Portuguese) https://doi.org/10.22408/reva412019211749-761

[3] Brasil, Law $n^{\circ}$ 12.305, August 2, 2010, Brazilian Solid Waste Policy, DOU: Brasília, 2010 (in Portuguese)

[4] Ministério das Cidades (MCIDADES), National Basic Sanitation Information System: Diagnosis of Solid Waste Management, MCIDADES: Brasília, 2018

[5] Oliveira, B.O.S. \& Medeiros, G.A., "Municipal solid waste management in the Amazon: environmental, social, and economic problems, gaps, and challenges" WIT Transactions on Ecology and the Environment, vol. 245, WIT Press: Southampton and Boston, pp. 9-20, 2020. https://doi.org/10.2495/EID200021

[6] Dalagnol, R., Borma, L.S., Mateus, P. \& Rodriguez, D.A., Assessment of climate change impacts on water resources of the Purus Basin in the southwestern Amazon. Acta Amazonica, 47(3), pp. 213-226, 2017. https://doi.org/10.1590/1809-4392201601993

[7] Monteiro, K.F.G., Contributions for environmental management of supply chain of biofuel in the Brazilian Amazon and Colombian. Oecologia Australis, 15(2), pp. 351-364, 2011. (in Portuguese)

[8] Instituto Brasileiro de Geografia e Estatística (IBGE), Panorama of Humaitá city, https://cidades.ibge.gov.br/brasil/am/humaita/panorama. Accessed on: 21 Dec. 2020.

[9] Instituto Brasileiro de Geografia e Estatística (IBGE), Panorama of Manicoré city, https://cidades.ibge.gov.br/brasil/am/manicoré/panorama. Accessed on: 21 Dec. 2020.

[10] Instituto Brasileiro de Geografia e Estatística (IBGE), Panorama of Ariquemes city, https://cidades.ibge.gov.br/brasil/ro/ariquemes/panorama. Accessed on: 21 Dec. 2020.

[11] Tavares, L. \& Cordeiro, L., Socioeconomic and environmental profile of the South of the state of Amazonas: subsidies for landscape analysis, WWF: Brasília, 2017. (in Portuguese)

[12] Consórcio Intermunicipal de Saneamento da Região Central de Rondônia (CISAN), Regional Plan for Associated and Integrated Management of Solid Waste of the Intermunicipal Sanitation Consortium of the Central Region of Rondônia - CISAN, CISAN: Porto Velho, 2014. (in Portuguese)

[13] Geist, M.R., Using the Delphi method to engage stakeholders: a comparison of two studies. Evaluation and Program Planning, 33, pp. 147-154, 2010. https://doi.org/10.1016/j. evalprogplan.2009.06.006

[14] Kim, M., Jang, Y.C. \& Lee, S., Application of Delphi-AHP methods to select the priorities of WEEE for recycling in a waste management decision-making tool. Journal of environmental management, 128, pp. 941-948, 2013. https://doi.org/10.1016/j.jenvman.2013.06.049

[15] Kharat, M.G., Raut, R.D., Kamble, S. \& Kamble, S., The application of Delphi and AHP method in environmentally conscious solid waste treatment and disposal technology selection. Management of Environmental Quality, 27(4), pp. 427-440, 2016. https://doi.org/10.1108/MEQ-09-2014-0133

[16] Muchangos, L.S., Tokai, A. \& Hanashima, A., Application of the Delphi method to the identification of barriers to a waste management policy in Maputo city, Mozambique. Journal of Sustainable Development, 8(6), pp. 146-157, 2015. https://doi.org/10.5539/ jsd.v8n6p146

[17] Esmaeilizadeh, S., Shaghaghi, A. \& Taghipour, H., Key informants' perspectives on the challenges of municipal solid waste management in Iran: a mixed method study. Journal of Material Cycles and Waste Management, 22, pp. 1284-1298, 2020. https:// doi.org/10.1007/s10163-020-01005-6 
[18] Bui, T.D., Tsai, F.M., Tseng, M.L., Ali, M.H., Identifying sustainable solid waste management barriers in practice using the fuzzy Delphi method. Resources, Conservation \& Recycling, 154, pp. 104625, 2020. https://doi.org/10.1016/j.resconrec.2019.104625

[19] Diamond, I.R., Grant, R.C., Feldman, B.M., Pencharz, P.B., Ling, S.C., Moore, A.M. \& Wales, P.W., Defining consensus: a systematic review recommends methodologic criteria for reporting of Delphi studies. Journal of Clinical Epidemiology, 67(4), pp. 401-409, 2014. https://doi.org/10.1016/j.jclinepi.2013.12.002.

[20] Wang, Q., Long, X., Li, L., Kong, L., Zhu, X. \& Liang, H., Engagement factors for waste sorting in China: the mediating effect of satisfaction. Journal of Cleaner Production, 267, pp. 122046, 2020. https://doi.org/10.1016/j.jclepro.2020.122046

[21] Paes, M.X., Medeiros, G.A., Mancini, S.D., Bortoleto, A.P., Oliveira, J.A.P. \& Kulay, L.A., Municipal solid waste management: Integrated analysis of environmental and economic indicators based on life cycle assessment. Journal of Cleaner Production, 254, pp. 119848 https://doi.org/10.1016/j.jclepro.2019.119848

[22] Paes, M.X., Medeiros, G.A., Mancini, S.D., Ribeiro, F.M. \& Oliveira, J.A.P., Transition to circular economy in Brazil: a look of the municipal solid waste management in the state of São Paulo. Management Decision, 57, pp. MD-09-2018-1053, 2019. https://doi. org/10.1108/MD-09-2018-1053

[23] Lima, N.S.S. \& Mancini, S.D., Integration of informal recycling sector in Brazil and the case of Sorocaba City. Waste Management \& Research, 35(7), pp. 721-729, 2017. https://doi.org/10.1177/0734242X17708050

[24] Paes, M.X., Medeiros, G.A., Mancini, S.D., Gasol, C., Rieradevall-Pons, J. \& Gabarrell-Durany, X., Transition towards eco-efficiency in municipal solid waste management to reduce GHG emissions: the case of Brazil. Journal of Cleaner Production, 263, pp. 121370. https://doi.org/10.1016/j.jclepro.2020.121370

[25] Deus, R.M., Battistelle, R.A.G. \& Silva, G.H.R., Scenario evaluation for the management of household solid waste in small Brazilian municipalities. Clean Technologies and Environmental Policy, 19, pp. 205-214, 2017. https://doi.org/10.1007/s10098-016$\underline{1205-0}$

[26] Ibáñez-Forés, V., Coutinho-Nóbrega, C., Dolores-Bovea, M., Silva, C.M. \& Virgolino, J., Influence of implementing selective collection on municipal waste management systems in developing countries: a Brazilian case study. Resources, Conservation \& Recycling, 134, pp. 100-111, 2018. https://doi.org/10.1016/j.resconrec.2017.12.027

[27] Pavani, I.D., Cicerelli, R.E., de Almeida, T., Moura, L.Z. \& Contreras, F., Allocation of sanitary landfill in consortium: strategy for the Brazilian municipalities in the State of Amazonas. Environmental Monitoring and Assessment, 191(1), pp. 1-13, 2019. https:// doi.org/10.1007/s10661-018-7146-9

[28] Cobo, S., Dominguez-Tamos, A. \& Irabien, A., From linear to circular integrated waste management systems: a review of methodological approaches. Resources, Conservation \& Recycling, 135, pp. 279-295, 2018. http://dx.doi.org/10.1016/j.resconrec.2017.08.003

[29] Ministério Público Federal, Integrated solid waste management in the Amazon. IBAM, 2008. (in Portuguese)

[30] Consórcio Intermunicipal de Saneamento da Região Central de Rondônia (CISAN), Environmental impact report: expansion of the Ariquemes sanitary landfill, CISAN: Porto Velho, 2016. (in Portuguese) 
[31] Agência Nacional de Transportes Aquaviários (ANTAQ), Brazilian waterways: freigth transport indicators, ANTAQ: Brasilia, 2014. (in Portuguese)

[32] Agência Nacional de Transportes Aquaviários (ANTAQ), Freight transport on Brazilian waterways: Madeira waterway, ANTAQ: Brasilia, 2011. (in Portuguese)

[33] Instituto Brasileiro de Geografia e Estatística (IBGE), @ Cidades, https://cidades.ibge. gov.br/ Accessed on: 21 Dec. 2020. 